\title{
PERTOBATAN SEBAGAI SARANA MENJADI MANUSIA BARU SUATU URAIAN SPIRITUALITAS- BELAJAR DARI PENGALAMAN HIDUP PAULUS
}

\author{
Yohanes AnjarDonobakti \& Stanislaus Kotska B.D.Atmaja* \\ Program Studi Ilmu Filsafat, Fakultas Filsafat, Unika Santo Thomas \\ Email: johanesadb2015@yahoo.com
}

\begin{abstract}
Abstrak
Sepanjang sejarah keselamatan, Allah tak henti-hentinya mewartakaan pertobatan. Puncak karya keselamatan itu ada dalam diri Yesus yang datang dalam dunia. Yesus telah berkata, "Waktunya telah genap; Kerajaan Allah sudah dekat. Bertobatlah dan percayalah kepada Injil!" (Mrk 1:15). Gereja terusmenerus menyerukan dan melayani pertobatan kepada semua orang supaya mereka memperoleh keselamatan kekal. Namun, kerapuhan seringkali menjadi alasan manusia jatuh dalam dosa, jauh dari Allah, dan berada dalam ketidakkudusan. Tetapi Allah tetap setia pada manusia dan menghendaki agar manusia menjadi kudus melalui pertobatan. Pertobatan merupakan sarana untuk memulihkan relasi antara manusia dengan Allah. Santo Paulus melalui pengalaman pertobatannya yang luar biasa menjadi teladan dan model bagi setiap orang Kristen untuk bertobat, berbalik kepada Allah, dan hidup baru yang sesuai dengan kehendak Allah.
\end{abstract}

Kata-kata Kunci: Pertobatan, Paulus, Manusia baru, dan Hidup baru.

\section{Pengantar}

Dewasa ini, seiring perkembangan ilmu pengetahuan dan teknologi, kesadaran akan diri sebagai manusia yang berdosa dan keinginan manusia untuk bertobat terasa mulai luntur. Banyak orang yang berdosa tidak mengaku dosa di hadapan imam, atau bahkan menghindari pengakuan dosa dan mencari keselamatan serta kesembuhan yang bukan berasal dari Allah. Pandangan tentang dosa dan hukuman seolah-olah tidak ada kaitannya dengan misteri keselamatan Allah dan

\footnotetext{
* Yohanes Anjar Donobakti, Doktor of Philosophy; Southeast Asia Interdisciplinnary Development Institute; dosen tetap pada Fakultas Filsafat Unika St. Thomas, Sumatera Utara. Stanislaus Kotska Bima Dwi Atmaja adalah mahasiswa STFT St. Yohanes yang sedang menjalani masa Tahun Orientasi Pastoral 2021-2022.
} 
belaskasih-Nya. Akibatnya, hidup yang dijalani hanya mengalir begitu saja seolah-olah Tuhan tidak berpengaruh dalam kehidupan manusia. Rasa tidak berdosa menunjukkan bagian dari kehidupan manusia yang rapuh sehingga tidak ada kesadaran bahwa berbuat dosa itu menyakiti hati Tuhan. Fenomena ini kembali dipertegas oleh Paus Yohanes Paulus II yang mengatakan bahwa, "Orang mengidolakan cinta kepada diri dan kehebatan globalisasi daripada cinta kepada Tuhan."

Seruan pertobatan senantiasa diwartakan Gereja sampai saat ini dan selamanya. Seruan pertobatan membutuhkan jawaban, komitmen yang tegas dan total dari manusia untuk berbalik kepada Allah serta hidup menjadi manusia baru sesuai dengan kehendak-Nya. Melalui ajaran resmi Gereja terutama sakramen tobat, Gereja memberikan sarana yang tepat bagi manusia yang bertobat. Sepanjang sejarah Gereja sudah banyak orang menanggapi panggilan Allah yang penuh cinta, bertobat, dan hidup sesuai dengan kehendak Allah. Mereka bisa menjadi teladan bagi kita untuk menanggapi cinta dan panggilan Allah tersebut.

Pertobatan Paulus adalah salah satu contoh orang yang menanggaai cinta dan panggilan Allah itu. Sebelum bertobat, Paulus adalah seorang penganiaya Kristus. Setelah bertobat, Paulus menjadi pengikut Kristus bahkan diangkat menjadi Rasul Yesus bagi para bangsa. Pertobatannya berawal dari pengalaman istimewa ketika disapa oleh Yesus dalam perjalanannya menuju ke Damsyik. Paulus telah sadar bahwa tindakan yang pernah dilakukannya itu salah dan dosa, kemudian ia tergerak untuk bertobat. Manusia lama Paulus telah ditanggalkan dan ia mengenakan manusia baru sesuai kehendak Allah. Perjalanan hidup Paulus selanjutnya berorientasi pada Kristus yang telah mewahyukan dan memanggilnya untuk menjadi saksi Kristus dan pewarta Injil kepada bangsa-bangsa.

\section{Sekilas Tentang Paulus dan Pertobatannya}

Paulus adalah orang Yahudi, lahir di Tarsus, Kilikia dan mempunyai kewarganegaraan Romawi. Sejak kecil Paulus sudah mendapat pengajaran agama di sinagoga dan di sekolah khusus untuk

\footnotetext{
${ }^{1}$ Laurensius Dihe S, Sakramen Tobat di Tengah Globalisasi (Yogyakarta: Kanisius, 2015), hlm. 13-14, 20.
} 
anak-anak Yahudi. $^{2}$ Orangtua dan lingkungan sangat mempengaruhi kehidupannya sehingga dia menjadi anak yang cerdas.

Paulus melanjutkan pendidikan untuk menjadi rabbi di Yerusalem. Di Yerusalem Paulus dididik dan diasuh oleh Gamaliel seorang Farisi dan juga salah seorang anggota Sanhendrin. ${ }^{3}$ Pendidikannya membuat dirinya bersemangat dengan jiwa membara dalam kepentingan tradisi nenek moyang. Semua pendidikan yang didapatnya membuat Paulus lebih maju dari banyak teman sebaya di antara bangsanya (Lih. Gal 1:14). Paulus muda, yang telah mendapat gelar Farisi sekaligus menjadi orang Farisi menurut mazhab yang paling keras dalam agama Yahudi, secara tegas dan keras pula mempertahankan nilai-nilai keagamaan Yahudi (Lih. Kis 26:5; Flp 3:4-6). Ia sangat terlatih dalam menggunakan Kitab Suci untuk membuktikan pandangannya. ${ }^{4}$

Setelah pendidikannya di Yerusalem selesai, Paulus kembali ke Tarsus dan mulai mencari nafkah sebagai pembuat dan pedagang tenda. Pekerjaan itu tidak menghalangi dia untuk menjadi aktivis Farisi yang membina iman orang-orang Yahudi di Tarsus dan sekitarnya. Dalam melaksanakan tugas sebagai pembina umat, ia mempersiapkan diri dan berusaha menguasai Kitab-kitab Suci Yahudi. ${ }^{5}$

Sebagai orang Farisi, Paulus memusuhi Yesus Kristus karena pengajaran-Nya dianggap melanggar Hukum Taurat. Ajaran Yesus yang melanggar Hukum Taurat yaitu bekerja pada hari Sabat dan menyatakan bahwa semua makanan halal. ${ }^{6}$ Hal ini membuat Paulus terpisah secara total dengan inti ajaran iman jemaat pengikut Yesus (Kristen). Ketaatannya pada Hukum Taurat mendorong Paulus menjadi penganiaya pengikut Yesus. Iman Kristen yang menyatakan bahwa Yesus adalah

\footnotetext{
2 Al. Purwa Hadiwardoyo, Warisan Paulus Bagi Umat: Ajaran Iman, Pastoral, dan Moral (Yogyakarta: Kanisius, 2012), hlm. 13.

3 Sanhedrin adalah kaum Saduki, tetapi ada juga sekelompok kecil kaum Farisi yang percaya pada kuasa Tuhan dalam membangkitkan orang mati, sedangkan orang saduki tidak percaya. [Lihat Peter Walker, In The Step Of Saint Paul, (Judul asli: In The Steps of Saint Paul, Lion Publishing Oxford, England, 2008), diterjemahkan oleh V. Indra Sanjaya (Yogyakarta: Kanisius, 2013), hlm. 160.]

${ }^{4}$ YM Seto Marsunu, Pengantar Surat-surat Paulus (Yogyakarta: Kanisius, 2020), hlm. 14-15.

${ }^{5}$ Al. Purwa Hadiwardoyo, Warisan Paulus Bagi Umat..., hlm. 13-14.

${ }^{6}$ YM Seto Marsunu, Pengantar Surat-surat Paulus ..., hlm. 18.
} 
Mesias, Anak Allah, menjadi permasalahan bagi Paulus dan orang-orang Yahudi pada zaman itu. ${ }^{7}$

Paulus bereaksi keras terhadap orang-orang yang percaya pada Yesus. Dengan penuh keyakinan dan amarah, ia harus berusaha dengan sekuat tenaga untuk menghentikan ajaran itu. Dengan izin para pemimpin agama Yahudi ia mengejar-mengejar para pengikut Kristus dan memasukkan mereka dalam penjara. Dengan kejam Paulus menganiaya mereka dan setuju bila mereka dijatuhi hukuman mati (Kis 26:9-11). Paulus yakin bahwa apa yang dilakukannya benar dan sesuai dengan kehendak Allah. ${ }^{8}$

Awal pengejaran dan penganiayaan dilakukan Paulus di Yerusalem, kemudian diperluas sampai ke luar Yerusalem. ${ }^{9}$ Berbekal surat kuasa dari Imam Besar untuk majelis Yahudi di Damsyik, Paulus merencanakan penganiayaan besar-besaran terhadap pengikut Yesus di sana (Kis 9:1-2). Dengan hati yang berkobar-kobar dan penuh kebencian, Paulus menuju Damsyik bersama rekan-rekan Yahudinya menggunakan kuda. Ia tahu bahwa banyak penghianat Yahudi telah meninggalkan ibukota untuk mencari perlindungan di Damsyik. ${ }^{10}$

Dalam perjalanan menuju Damsyik untuk menangkap dan menganiaya para pengikut Yesus, Paulus dijumpai dan disapa oleh Yesus yang menampakkan diri dalam rupa cahaya yang memancar dari langit berserta suara Yesus yang berkata kepadanya: "Saulus, Saulus, mengapakah engkau menganiaya Aku?" Jawab Saulus: "Siapakah Engkau, Tuhan?” Kata-Nya: “Akulah Yesus yang kauaniaya itu. Tetapi bangunlah dan pergilah ke dalam kota, disana akan dikatakan kepadamu,

\footnotetext{
7 St. Eko Riyadi, Hidup Dalam Kristus: Pengalaman Rohani St. Paulus dalam Peristiwa Di Damsyik (Yogyakarta: Kanisius, 2012), hlm. 18-20; bdk. I. Suharyo, Paulus Rasul Bangsabangsa (Jakarta: Lembaga Biblika Indonesia, 2008), hlm. 9; bdk juga. C. Groenen, Pengantar Ke Dalam Perjanjian Baru (Yogyakarta: Kanisius, 2006), hlm. 211.

${ }^{8}$ YM Seto Marsunu, Pengantar Surat-surat Paulus ..., hlm. 18-19; bdk. Lihat Peter Walker, In The Step Of Saint Paul ..., hlm. 21-22.

${ }^{9}$ V. George Shillington, Jesus And Paul Before Christianity (Eugene-Oregon: Cascade Books, 2011), hlm. 112; bdk. St. Eko Riyadi, Hidup Dalam Kristus ..., hlm. 29-31.

10 N.T. Wright, What Saint Paul Really Said Was Paul Of Tarsus The Real Founder Of Christianity (England: Lion Publishing PK, 2002), hlm. 35; bdk. St. Eko Riyadi, Hidup Dalam Kristus ..., hlm. 31; bdk juga. Charles R. Swindoll, Paulus: Seorang Yang Penuh Kasih dan Tegar (Jakarta: Nafiri Gabriel, 2004), hlm. 32.
} 
apa yang harus kauperbuat (Kis 9:3-6)."11 Peristiwa itu membuat Paulus jatuh ke tanah. ${ }^{12}$

Berkat perjumpaan itu, Paulus mengubah sikap hidupnya dan bertobat. Pertobatannya menjadi awal hidupnya sebagai manusia baru. Ia melihat pertobatannya sebagai anugerah istimewa baginya (Gal 1:13; 1Kor 15:9; Flp 3:6). Paulus menyadari bahwa pertobatannya merupakan sebuah panggilan dan perutusan untuk mewartakan Injil.

Paulus meninggalkan warisan iman dan rohani dalam suratsuratnya. Surat-surat yang ditulis dan disampaikan oleh Paulus kepada jemaat harus dibaca supaya iman mereka dikuatkan, diteguhkan, dan ajaran iman tersebut dapat dihidupi oleh jemaat. Melalui surat-suratnya termuat pesan kehidupannya sebagai orang beriman dan rasul yang gigih dalam mewartakan kabar gembira. ${ }^{13}$

\section{Pertobatan Sebagai Sarana Menjadi Manusia Baru}

\section{Konsep dan Cakupan Tobat}

Pertobatan selalu terkait dengan aspek religius dan moral, meskipun pada dasarnya lebih mendalam dibicarakan dalam aspek religius. Pertobatan menyangkut sikap atau pendirian seseorang terhadap Injil Kristus dan penerimaan kabar gembira keselamatan. Sikap seseorang yang bertobat tampak dalam perubahan (pembaruan) spiritual secara mendasar dan menyeluruh, sehingga pada akhirnya menunjukkan pembaruan hidup secara total. Pertobatan sebagai pembaruan hidup membutuhkan sebuah proses terus-menerus dan melewati langkahlangkah yang tepat yaitu: contritio (penyesalan), confessio (pengakuan), dan satisfactio (perbaikan atau penitensi). ${ }^{14}$

Penyesalan adalah sikap yang lahir dari kesadaran akan dosa dan keterbukaan kepada rahmat pengampunan. Sikap penyesalan tidak hanya sadar dan terbuka akan pengampunan dari Allah, tetapi juga dorongan

\footnotetext{
${ }^{11}$ A. Brunot, Paulus dan Pesannya (Yogyakarta: Kanisius 1992), hlm. 26.

${ }^{12}$ I. Suharyo, Paulus Rasul Bangsa-Bangsa ..., hlm. 12.

13 Al. Purwa Hadiwardoyo, Warisan Paulus Bagi Umat ..., hlm. 10; bdk. St. Darmawijaya, Sekilas Bersama Paulus (Yogyakarta: Kanisius, 1992), hlm. 125.

14 Peter C. Aman, Moral Dasar: Prinsip-prinsip Hidup Kristiani (Jakarta: Obor, 2016), hlm.182.
} 
dari hati terdalam untuk membalas kasih Allah dalam sakramen pengakuan dosa. Allah menerima pendosa yang berniat untuk bertobat dan mengampuninya karena terdapat penyesalan dan pengakuan dari si pendosa. Mengampuni tidak hanya sebatas melupakan atau menutupi dosa, tetapi memampukan orang yang telah bertobat memperbaiki dan mengatasi kelemahannya. Perbaikan (satisfactio) terhadap dosa dilakukan dalam niat untuk tidak mengulangi dosa yang merusak relasi dengan Allah dan hidup seturut dengan Injil Kristus. ${ }^{15}$

\section{Pertobatan dalam Kitab Suci}

Pengalaman akan keberdosaan yang mendorong manusia untuk bertobat dapat dilihat dalam pengalaman umat Israel dalam Perjanjian Lama dan umat Kristen Perjanjian Baru. Pertobatan dalam Perjanjian Lama merupakan proses atau tindakan manusia untuk berbalik kepada Allah yang benar. Proses itu membutuhkan gerakan hati secara total untuk berani mengakui dosa-dosa dan kembali pada persekutuan dengan Allah. ${ }^{16}$ Hal ini dipertegas kembali oleh Nabi Yesaya yang berkata: Sebab beginilah firman Tuhan Allah, Yang Mahakudus, Allah Israel: "Dengan bertobat dan tinggal diam kamu akan diselamatkan, dalam tinggal tenang dan percaya terletak kekuatanmu." (Yes 30:15). ${ }^{17}$

Pertobatan dalam Perjanjian Baru dilukiskan dengan tiga kata, yaitu menyesal (Mat 21:30.32), berbalik (Luk 12:44), dan bertobat (Mrk 1:15). Secara singkat dapat dikatakan bahwa bertobat adalah bagian dari iman orang yang berdosa. Proses pertobatan tidak hanya berarti meninggalkan hidup lama (dosa), berbalik kepada Allah, menyerahkan diri kepada Allah, tetapi juga memulai hidup yang baru. ${ }^{18}$

\footnotetext{
15 Peter C. Aman, Moral Dasar ..., hlm. 200-202; bdk. Laurensius Dihe S, Sakramen Tobat di Tengah Globalisasi ..., hlm. 51-52; bdk juga. Albertus Sujoko, Praktek Sakramen Pertobatan dalam Gereja Katolik: Tinjanan Historis, Dogmatis, dan Pastoral (Yogyakarta: Kanisius, 2012), hlm. 68-69; bdk. Albertus Sujoko, Belajar Menjadi Manusia: Berteologi Moral Menurut Bernard Häring, CSsR (Yogyakarta: Kanisius, 2012), hlm. 78-79.

16 Largus Nadeak, Topik-topik Teologi Moral Fundamental (Medan: Bina Media Perintis, 2015), hlm. 132-133.

17 Al. Purwa Hadiwardoyo, Pertobatan Dalam Tradisi Katolik (Yogyakarta: Kanisius, 2011), hlm. 13.

${ }^{18}$ Tom Jacob (ed), Rahmat Bagi Manusia Lemah (Yogyakarta: Kanisius, 2004), hlm. 13-18.
} 
Pertobatan dilihat sebagai jawaban manusia atas tawaran kerahiman Allah. Walaupun jarak antara Allah dan manusia yang berdosa itu jauh, tetapi pertobatan membuat manusia mampu menyadari betapa besar kebaikan dan kasih Allah, sehingga manusia berdosa mampu menjalin relasi yang dekat dengan Allah. Pertobatan membutuhkan keterbukaan, kerendahan hati, keberanian untuk hidup baru, mengakui Allah sebagai sumber kehidupan, dan mengalami Allah sebagai kasih tanpa batas. ${ }^{19}$

\section{Seruan Gereja untuk Pertobatan}

Gereja terus menerus menyerukan pertobatan dan menyediakan sarana pertobatan bagi umat beriman yang bertobat dan hidup suci melalui penerimaan sakramen tobat. Gereja tetap setia dalam perutusannya untuk mewartakan dan mengajak umat beriman bertobat. Pertobatan tertuju pada peralihan manusia lama kepada manusia baru yang sempurna dalam Kristus sehingga memperoleh sukacita tanpa batas dari Allah. $^{20}$

Keharusan menerima sakramen tobat termuat dalam Kitab Hukum Kanonik 1983. Penjelasan dan pemahaman pertobatan terdapat dalam kanon 959 yang mengatakan: Dalam sakramen tobat, umat beriman mengakukan dosa-dosanya kepada pelayan yang legitim, menyesalinya serta berniat untuk memperbaiki diri, lewat absolusi yang diberikan oleh pelayan itu, memperoleh pengampunan dari Allah atas dosa-dosa yang telah dilakukannya sesudah baptis, dan sekaligus diperdamaikan kembali dengan Gereja yang mereka lukai dengan berdosa. ${ }^{21}$

\section{Pertobatan Paulus Menjadi Manusia Baru}

Keseluruhan peristiwa hidup Paulus membuat dirinya membuka hati dengan mengakui diri sebagai pendosa, kemudian mengalami kerahiman Allah dan mau bertobat untuk membentuk diri menjadi manusia baru dalam perjalanan hidup selanjutnya. Bagi Paulus,

\footnotetext{
${ }_{19}$ Tom Jacob (ed), Rahmat Bagi Manusia Lemah ..., hlm. 35-36.

${ }^{20}$ Konsili Vatikan II, "Dekrit Tentang Kegiatan Misioner Gereja" (Ad Gentes), dalam Dokumen Konsili Vatikan II, diterjemahkan oleh R. Hardawiryana (Jakarta: Dokumentasi dan Penerangan KWI-OBOR, 1993), no. 13.

${ }^{21}$ Konferensi Waligereja Indonesia, Kitab Hukum Kanonik (Bogor: Grafika Mardi Yuana, 2016).
} 
pertobatan akan menjadikan manusia ciptaan baru karena Allah telah memperdamaikan orang yang berdosa kepada diri-Nya dan hidup di dalam-Nya (2Kor 5:17-19). ${ }^{22}$

\section{Perjumpaan Paulus dengan Yesus dan Dampaknya}

Dalam rencana perjalanan untuk menganiaya pengikut Yesus, Paulus diberhentikan oleh Yesus dalam rupa cahaya yang terang dan suara yang menyapanya. Dalam diri Paulus, ia menyadari betapa indahnya perjumpaan dengan Yesus yang secara bertahap telah mengubah kehidupannya. Paulus menyadari bahwa kehidupannya berubah total karena Allah telah menunjukkan kemuliaan-Nya dalam cahaya di perjalanan menuju Damsyik. Paulus juga menyadari dirinya yang berada dalam kegelapan berubah menjadi terang karena perjumpannya dengan wajah Kristus secara langsung. ${ }^{23}$

\section{Pantulan Kecemerlangan Allah}

Paulus jatuh setelah dijumpai oleh Yesus dalam rupa cahaya. Kemudian Paulus bangun dan berdiri, lalu membuka matanya, tetapi ia tidak dapat melihat apa-apa. Kawan seperjalanannya harus menuntun dia masuk ke Damsyik. Tiga hari lamanya ia tidak dapat melihat dan tidak makan dan minum" (Kis 9:8-9). Pantulan cahaya Krisrus itu mengakibatkan Paulus menjadi buta matanya. Pantulan cahaya kemuliaan Kristus menerangi kegelapan hati Paulus sehingga ia bisa melihat dan mengenal Krisrus. Cahaya itu sebagai titik awal perubahan hidupnya. Pengalaman tersebut diungkapkan Paulus: "Sebab Allah yang telah berfirman, dari dalam gelap akan terbit terang" (2Kor 4:6; bdk. Kej 1:3). Paulus menuliskan ini berdasarkan pengalaman hidupnya yang terjadi di dalam perjalanannya menuju Damsyik untuk menganiaya pengikut Kristus. ${ }^{24}$

\section{Kebutaan Paulus Disembuhkan}

Perjalanan Paulus dalam rencana menganiaya pengikut Yesus sama sekali tidak terjadi. Penganiayaan itu malah terjadi pada diri Paulus sendiri yang ditandai dengan kebutaan pada kedua matanya dan keadaan

${ }^{22}$ N.T. Wright, What Saint Paul Really Said ..., hlm. 39.

${ }^{23}$ V. George Shillington, Jesus And Paul Before Christianity ..., hlm. 118-120.

${ }^{24}$ I. Suharyo, Paulus Rasul Bangsa-Bangsa ..., hlm. 14-15; bdk. Peter Walker, In The Step Of Saint Paul ..., hlm. 19. 
yang tidak berdaya. Paulus harus mendapat bantuan dari orang lain. Ia harus dituntun oleh para pengiringnya masuk ke dalam kota Damsyik agar dapat beristirahat di rumah orang yang bernama Yudas yang tinggal di jalan bernama Jalan Lurus. Meski mata fisiknya buta, tetapi mata hati Paulus terbuka sehingga dapat melihat kemuliaan dan kebenaran Allah.

Allah tidak membiarkan keadaan Paulus berkepanjangan. Kebutuaan Paulus disembuhkan oleh Ananias. Allah memberi pesan kepada Ananias untuk menemui Paulus dan meletakkan tangannya di atas Paulus supaya dia dapat melihat lagi. Allah juga mengatakan kepada Ananias bahwa apapun yang telah dilakukan Paulus di masa lalu, sekarang tidak menjadi permasalahan lagi, karena Paulus dipersiapkan untuk menjadi salah seorang hamba yang paling besar bagi Kristus, juga untuk membawa Kabar Gembira dari Allah kepada banyak orang di berbagai bangsa. ${ }^{25}$

\section{Penghayatan Paulus akan Pertobatannya}

Peristiwa dalam perjalanan ke Damsyik dan pertobatannya tidak hanya mengubah arah tujuan Paulus, tetapi mengubah cara hidup dan melihat segalanya dengan cara baru. Peristiwa di Damsyik itu membekas dalam hidup Paulus. Paulus menjadi yakin bahwa rencana dan karya Allah begitu nyata dalam dirinya. Paulus belajar bahwa ternyata ia bisa juga keliru. Semangat keagamaannya ternyata tidak pada tempatnya; kesetiannya pada Hukum Taurat telah menyesatkan. Paulus mengakui bahwa ia lebih berdosa daripada yang ia ketahui. Paulus sudah hancur, tetapi dipulihkan kembali; ia tercampak, tetapi dibangkitkan kembali. Bagi Paulus, mengikuti Yesus sekarang ini menjadi tujuan utama hidupnya. Segalanya menunjukkan rahmat yang tidak terduga dan merasa tidak pantas menerimanya, seperti dikatakan oleh Paulus:

"Aku yang tadinya seorang penghujat dan seorang penganiaya dan seorang yang ganas tetapi telah dikasihani-Nya karena semuanya itu telah kulakukan tanpa pengetahuan, yaitu di luar iman. Malah anugerah Allah kita itu telah dikaruniakan dengan limpahnya kepadaku dengan iman dan kasih dalam Kristus Yesus.

\footnotetext{
25 William Barclay, Duta Bagi Kristus: Latar Belakang Perjalanan Paulus, (Judul asli: Ambassador for Christ: the life and teaching of Paul), diterjemahkan oleh D. Susilaradeya dan A. Susilaradeya (Jakarta: Gunung Mulia, 2009), hlm. 60-62.
} 
Perkataan ini benar dan patut diterima sepenuhnya, "Kristus Yesus datang ke dunia untuk menyelamatkan orang berdosa", dan di antara mereka akulah yang paling berdosa (1Tim 1:13-15)., ${ }^{, 26}$

Setelah sadar akan kedosaannya dan bertobat, Paulus semakin percaya pada kuasa dan kasih Yesus yang menyelamatkan bekerja dalam dirinya. Paulus menangkap bahwa baginya yang pokok adalah Kristus. Semua yang ia lakukan, kerjakan, dan wartakan nantinya bukanlah apaapa, jika Kristus tidak hidup dalam dirinya. Paulus secara tegas mengatakan, "Bagiku hidup adalah Kristus dan mati adalah keuntungan" (Flp 1:21). ${ }^{27}$

\section{Transfigurasi Paulus}

Transfigurasi diartikan sebagai perubahan sangat mendalam yang dicapai oleh Paulus melalui pemurnian batinnya. Titik tolak dalam transfigurasi ialah transfigurasi Kristus. "Ketika Ia sedang berdoa, rupa wajah-Nya berubah dan pakaian-Nya menjadi putih berkilau-kilau" (Lukas 9:29). Dalam cahaya cemerlang yang menyinari Paulus dalam perjalanannya ke Damsyik, Paulus diliputi kemuliaan Tuhan. Tindakan perubahan itu terjadi terus-menerus dalam kemuliaan yang semakin besar. Paulus berubah menurut gambar Yesus dan menerima kecermelangan Kristus. $^{28}$

Tanda transfigurasi yang nyata dari Paulus adalah baptisan yang ia terima dari Ananias. Pada waktu itu dia berpakaian putih-putih dan seluruh tubuhnya dibenamkan ke dalam air bersih. Perasaan Paulus saat dibenamkan ke dalam air seperti dikubur dan ketika ia muncul lagi dari dalam air, rasanya seperti ia bangkit lagi dari kubur. Paulus lama, yang tadinya adalah musuh kejam dari Yesus, telah mati dan seorang Paulus yang baru, yang bersumpah menjadi hamba Yesus, telah bangkit menggantikan tempatnya (Rm 6:4-6). ${ }^{29}$

\footnotetext{
${ }^{26}$ Peter Walker, In The Steps Of Saint Paul (Oxford: Lion Publishing, 2008), diterjemabkean oleh V. Indra Sanjaya (Yogyakarya: Kanisius, 2013), hlm. 22-23.

${ }^{27}$ C.M. Martini, Kesaksian Santo Paulus (Yogyakarta: Kanisius, 2001), hlm. 84-85.

${ }^{28}$ C.M. Martini, Kesaksian Santo Paulus ..., hlm. 86-88.

${ }^{29}$ William Barclay, Duta Bagi Kristus. (Judul asli: Ambrassador for Christ: The Life and Teaching of Paul (The Saint Andrew Press, 1980), diterjemahkan oleh D. Susilaradeya dan A. Susilaradeya (Jakarta: Gunung Mulia, 2009), hlm. 63.
} 
Transfigurasi Paulus membuat dirinya bertambah kecermelangan dan kejernihan terjadi sepanjang perjalanan hidupnya sebagai hamba Yesus. Paulus membuka hati akan Tuhan yang meamnggil dan membimbingnya. Perubahan sikap yang selama ini terjadi dalam hidup Paulus memang berasal dari dalam dirinya sendiri karena ia berani menerima cahaya kebangkitan Yesus Kristus yang selama ini menerangi hati Paulus sehingga ia mampu bertobat ${ }^{30}$ dan menjadi saksi Kristus. Transfigurasi Paulus tampak dalam sikap-sikap batin dan lahir.

\section{Sikap-sikap Batin}

Sikap batin pertama ditemukan dalam transfigurasinya adalah suatu sukacita batin dan kedamaian yang besar. Paulus berkata, "Dalam segala penderitaan kami, aku sangat terhibur dan sukacitaku melimpahlimpah" (2Kor 7:4). Sukacita luar biasa itu datang dari Allah karena Paulus tidak mampu memperolehnya sendiri. Sukacita berlimpah itu tidak hanya bagi dirinya sendiri, melainkan terpancar juga bagi jemaah yang dibentuknya. Sikap batin kedua adalah kemampuan bersyukur. Paulus sebagai rasul menyatukan sukacita dengan ucapan syukur. Sebagai rasul, Paulus mendapatkan anugerah Allah berupa kemampuan untuk selalu melihat yang baik. Ucapan syukur yang setiap kali ada dalam suratnya menunjukkan ia mampu menilai pertama-tama segi positif yang ada dalam jemaat yang dibentuknya. Mata imannya memungkinkan melihat bahwa sebutir iman yang ada pada kaum kafir yang bertobat itu merupakan anugerah begitu besar sehingga ia memuji Allah tanpa henti-hentinya. Sikap batin ketiga adalah pujian. Dalam tulisan Paulus terdapat pujian-pujian mengagumkan. Pujian itu mencakup semua segi kehidupan jemaah dalam Kristus, misalnya: "Terpujilah Allah dan Bapa Tuhan kita Yesus Kristus yang dalam Kristus telah mengaruniakan kepada kita segala berkat rohani di dalam surga" (Ef 1:3). Pujian yang ada dalam surat-surat Paulus dikenal sebagai doa Paulus. Melalui doa itu, Paulus menghargai saat-saat hidupnya yang paling gelap. Hal ini ia ungkapkan dalam surat keduanya kepada jemaah di Korintus:

"Terpujilah Allah, Bapa Tuhan kita Yesus Kristus, Bapa yang penuh belas kasihan Allah sumber segala pengiburan, yang

\footnotetext{
${ }^{30}$ C.M. Martini, Kesaksian Santo Paulus ..., hlm. 88.
} 
menghibur kami dalam segala penderitaan kami, sehingga kami sanggup menghibur mereka, yang berada dalam bermacammacam penderitaan dengan penghiburan yang kami terima dari Allah" (2Kor 1:3-4). ${ }^{31}$

\section{Sikap-sikap Lahir}

Ada dua sikap lahir Paulus yang disebutkan disini. Pertama, kemampuan mengagumkan dan tanpa lelah setiap kali mulai lagi perutusannya. Sejak hari pertama pertobatannya, Paulus berkhotbah di Damsyik dan melarikan diri, pergi ke Yerusalem untuk berkhotbah tetapi diusir, kemudian tinggal di Tarsus sampai penyelenggaraan Ilahi memanggilnya kembali. Setelah dipanggil kembali, ia melupakan kekecewaan masa lalunya. Ia berangkat lagi untuk memulai kembali perjalanan perutusannya ke tempat lain. Paulus adalah orang yang tidak mudah menyerah. Kemauan dan kemampuan Paulus untuk setiap kali mulai perutusan itu bukan sifat manusiawi belaka, melainkan berasal dari pantulan daya kasih Allah yang tidak berkesudahan (1Kor 5:5). Kasih Allah yang dialami Paulus menimbulkan ketekunan, tahan uji, dan pengharapan. Paulus memperoleh kekuatan Kristus untuk bangkit dari kelemahannya, karena Kristus telah hidup di dalam dirinya. Kedu, kebebasan roh. Kebebasan yang dimaksudkan Paulus merupakan kesadaran menjadi milik Kristus secara mutlak dan penuh, serta menjadi hamba-Nya. Paulus mengutarakan bahwa menjadi hamba Kristus itu sejajar dengan menjadi bebas terhadap semua pandangan manusiawi. Kebebasan menjadi suatu bentuk ketangguhan dalam pelayanan Paulus (Gal 5:1-13). Hal ini juga menjadi ciri pelayanan Paulus dengan segala kerendahan hatinya. ${ }^{32}$

\section{Sengsara Paulus, Sengsara Kristus}

Paulus menjadi saksi Kristus bukan hanya melaui khotbahkhotbah atau pidato-pidato yang menggetarkan tetapi, juga pada waktu membela diri di pengadilan, kerelaannya di dipenjara demi Kristus. Peristiwa pertama yang menjadi perbandingan sengsara Paulus dan sengsara Kristus adalah penangkapan yang dialami Paulus. Kristus ditangkap karena penghianatan dari murid-Nya sendiri yaitu Yudas

\footnotetext{
${ }^{31}$ C.M. Martini, Kesaksian Santo Paulus ..., hlm. 89-91.
}

${ }^{32}$ C.M. Martini, Kesaksian Santo Paulus ..., hlm. 92-95. 
Iskariot (Luk 22:47-49). Paulus mengalami penangkapan pada saat ia berkhotbah di Bait Allah dan setelah itu dimasukkan ke dalam penjara. Paulus dan Kristus ditangkap pada saat mereka membaktikan diri dalam karya pelayanan dan pengajaran kepada orang-orang yang dijumpainya. Peristiwa kedua adalah Kristus dan Paulus berada di muka pengadilan. Kristus dihadapkan ke berbagai pengadilan: di Mahkamah Agama, di pengadilan Pilatus, diinterograsi dengan berbagai tuduhan. Paulus juga mengalami proses pengadilan: di Mahkamah Agama, di hadapan Feliks (Kis 24), Festus (Kis 25) dan Raja Agripa (Kis 26). Kristus tidak memberikan perlawanan atas tuduhan terhadapnya. Sedangkan Paulus mengucapkan banyak pidato pembelaan diri. ${ }^{33}$

Paulus pernah dipenjara, didera dan dirajam yang bagi dirinya adalah suatu kejadian yang memang diharapkannya. Paulus juga mengalami penderitaan moral yang sangat lama, sampai akhir hidupnya ia merasa semakin ditinggalkan oleh murid-muridnya. Akhirnya ia mengucapkan pernyataan bahwa ia lelah dan sudah menderita sampai batas kekuatannya. Paulus bergulat dengan kesulitan sehari-hari dalam kesunyiannya, bahkan ia menjadi pesimis. Ia seakan tidak memiliki kekuatan, optimisme, dan antusiasme lagi. Paulus juga merasakan kegelapan batin ditinggalkan oleh Allah, tanpa hiburan. Imannya diliputi oleh kegelapan dan ia berjalan maju dengan kenangan akan seluruh kekayaan dan kekuatan Allah yang pernah dialaminya tetapi sekarang tidak lagi dirasakannya. ${ }^{34}$

Pengalaman Paulus akan Allah akhirnya mengubah penderitaan serta kelemahannya menjadi kekuatan dan pemurnian imannya. Pengalamannya akan Allah mengubah hidupnya, mengantar Paulus untuk bergerak menuju kekuatan yang berasal dari kelemahan dan penderitaannya. ${ }^{35}$ sebagaimana diungkapkan Paulus:

"Dan supaya aku jangan meninggikan diri karena pernyataanpernyataan yang luar biasa itu, maka aku diberi suatu duri di dalam dagingku, yaitu seorang utusan iblis untuk menggocoh aku,

\footnotetext{
${ }_{33}$ C.M. Martini, Kesaksian Santo Paulus ..., hlm. 100-101.

34 C.M. Martini, Kesaksian Santo Paulus ..., hlm. 102-104.

35 Thomas H. Tobin, Warta Rohani Rasul Paulus (Ende: Nusa Indah, 2009), hlm. 136-137; bdk. YM Seto Marsunu, Pengantar Surat-surat Paulus ..., hlm. 59-60.
} 
supaya aku jangan meninggikan diri. Tentang hal itu aku sudah tiga kali berseru kepada Tuhan, supaya utusan iblis itu itu mundur daripadaku. Tetapi jawab Tuhan kepadaku: "Cukuplah kasih karunia-Ku bagimu, sebab justru dalam kelemahanlah kuasa-Ku menjadi sempurna". Sebab itu terlebih suka aku bermegah atas kelemahanku, supaya kuasa Kristus turun menaungi aku. Karena itu aku senang dan rela di dalam kelemahan, di dalam siksaan, di dalam kesukaran, di dalam penganiayaan dan kesesakan oleh karena Kristus. Sebab jika aku lemah, maka aku kuat" (2Kor $12: 7-10) .^{36}$

Demikian pula dalam perjalanan hidupnya, orang kristiani akan mengalami pencobaan, ditinggalkan, menderita sengsara, dihina, dan ditolak sama seperti Kristus dan Paulus. Orang kristiani adalah manusia yang rapuh yang bisa jatuh, tetapi harus kuat dalam melewati saat-saat sulit. Kesadaran akan kerapuhan itu baik, tetapi memiliki kemauan dan keberanian menjalani panggilan hidupnya dengan keyakinan bahwa kekuatan, kuasa, dan kasih Allah pasti menolong. Orang kristiani sangat perlu menyadari adanya tantangan-tantangan, harus berani menghadapinya, dan tidak mudah menyerah, serta tetap mengandalkan Tuhan. ${ }^{37}$

\section{Menjadi Manusia Baru}

Paulus (Saulus) sebelum mengenal Kristus pernah melakukan kejahatan dengan cara menganiaya pengikut Kristus. Melalui peristiwa hidupnya dalam perjalanan menuju Damsyik, Paulus memperoleh kuasa Allah yang mengubah hidupnya, berbalik 180 derajak. Setelah bertobat, Paulus dengan gigih melayani Kristus. Kristus sangat berarti bagi hidupnya. Pernyataan itu serentak memberi tanda bahwa Paulus sudah menjadi manusia baru. ${ }^{38}$

Sebelum bertobat, hati Paulus tertutup oleh kebencian dan kejahatannya. Paulus menggambarkan situasi dan kondisi kehidupan manusia lama sebagai suatu yang rusak, tua, dan dihancurkan oleh

\footnotetext{
36 Thomas H. Tobin, Warta Rohani Rasul Paulus ..., hlm. 136.

${ }^{37}$ C.M. Martini, Kesaksian Santo Paulus ..., hlm. 106, 108-109.

${ }^{38}$ V. George Shillington, Jesus And Paul Before Christianity ..., hlm. 120-121.
} 
berbagai keinginan (Efesus 4:20-24). Manusia lama yang sudah rusak cenderung berbuat jahat. Dalam diri manusia lama itu, yang dikuasai kejahatan dan kebencian, harus dibersihkan dan diperbaharui oleh Roh Kudus agar tercipta hati, akal, perasaan, dan pemikiran manusia yang baru. Pertobatan Paulus menghasilkan suatu pikiran dan hati baru yang dipenuhi oleh Roh Allah. Manusia lama yang cenderung berbuat dosa sudah diganti oleh Kristus sendiri yang masuk ke dalam manusia lama dan mengubahnya menjadi manusia baru. Dalam surat-suratnya, Paulus mengatakan bahwa pertobatan menjadikan manusia (2Kor 5:17), mengalami pembenaran ( $\mathrm{Rm}$ 5:9-10), dan pengudusan (Kol 1:21:22). ${ }^{39}$

Ada beberapa hal yang mempengaruhi Paulus semakin matang menjadi manusia baru dalam Kristus. Pertama, Paulus dipengaruhi oleh tingkah laku orang-orang Kristen yang dianiaya. Paulus sungguh dikuatkan ketika melihat orang-orang Kristen menghadapi segala kesulitan dan bahaya maut dengan berani dan bersukacita, bahkan dengan tabah menanggung penyiksaan. Kesaksian iman orang Kristen, terutama yang terjadi pada Stefanus, ternyata membekas dalam hidupnya. ${ }^{40}$ Kedua, Paulus dikuatkan oleh pengalaman rohaninya sendiri dalam menghadapi Hukum Taurat. Kesetiaan dan ketaatannya pada hukum Taurat telah membuat Paulus gagal dalam memahami rencana Allah. Mengikut Yesus sekarang ini menjadi tujuan utama hidup Paulus. ${ }^{41}$

Ketiga, pengalamannya sendiri sebagai hamba Kristus yang sejati dan tangguh serta bijaksana dalam pelayanan. Paulus bangga menjadi hamba Kristus yang harus mewartakan Injil. Paulus melihat bahwa tugas tersebut sebagai anugerah Allah. Keempat, Paulus dikuatkan oleh kehidupannya yang baru dalam Kristus. Dalam suratnya kepada jemaat di Efesus, Paulus mengatakan bahwa segala berkat rohani dan puji-pujian telah disediakan Allah baginya yang sungguh telah bersatu dengan Kristus. Segala berkat tersebut mengalir dan mencukupi Paulus dalam setiap pelayanannya. Karena, dalam dan bersama Kristus, orang percaya

\footnotetext{
39 Kenneth D. Barney, Surat Efesus (Malang. Gandum Emas, 1981), hlm. 72-73; bdk. Seminari Tinggi Santo Paulus, Bermenung Bersama Santo Paulus Guru Bangsa-Bangsa (Yogyakarta: Kanisius, 2017), hlm. 220.

40 William Barclay, Duta Bagi Kristus ..., hlm. 43-49.

${ }^{41}$ Peter Walker, In The Step Of Saint Paul ..., hlm. 22-23; bdk. William Barclay, Duta Bagi Kristus ..., hlm. 48-51.
} 
akan terus-menerus menerima berkat yang tidak akan berakhir, yang berasal dari hati Bapa dan datang melalui Yesus. ${ }^{42}$

Menurut Paulus, hidup kristiani adalah hidup dalam Kristus. Kristus adalah titik tolak, dasar, sumber, arah, tujuan, dan pedoman hidup Kristiani. Hidup dalam Kristus sama halnya dengan hidup baik tetapi hidup yang baik ini harus berangkat dan menuju kepada Kristus. Pernyataan Paulus ini sebagaimana disampaikannya kepada jemaat di Kolose:

"Kamu telah menerima Kristus, Tuhan kita. Karena itu hendaklah hidupmu tetap di dalam Dia. Hendaklah kamu berakar di dalam Dia dan dibangun di atas Dia, hendaklah kamu bertambah teguh dalam iman yang telah diajarkan kepadamu, dan hendaklah hatimu melimpah dengan syukur" (Kol 2:6-7). ${ }^{43}$

Sebagai hamba yang hidup baru dalam Kristus, wajah Kristus terus terbayang-bayang di dalam diri Paulus. Paulus terus-menerus merenungkan dan membayangkan wajah Yesus Kristus saat pertama kali berjumpa dalam perjalanan ke Damsyik. Perjumpaan itu sangat berarti dan lebih mulia daripada semuanya. Wajah Yesus Kristus telah mengasihinya karena perbuatannya sebagai seorang penganiaya telah diubah menjadi seorang yang dipilih Allah menjadi rasul bagi para bangsa. Wajah Yesus mengajarkan Paulus untuk hidup dengan daya kasih, iman, dan karunia. ${ }^{44}$

Paulus telah merasakan kelimpahan terang dan cahaya yang mencerminkan kemuliaan Allah yang tampak pada wajah Kristus. Ungkapan ini sebagaimana yang ditulis oleh Paulus dalam suratnya yang kedua kepada jemaat di Korintus: Sebab Allah telah berfirman 'Dari dalam gelap akan terbit terang', Ia juga yang membuat terang-Nya bercahaya di dalam hati kita, supaya kita beroleh terang dan pengetahuan tentang kemuliaan Allah yang tampak pada wajah Kristus” (2Kor 4:6). Pengalaman perjumpaan dengan Kristus membuat Paulus ingat akan kisah penciptaan (Kej 1:3) dan ia memasukkan pengalaman itu ke dalam

42 Kenneth D. Barney, Surat Efesus ..., hlm. 4-6.

43 Al. Purwa Hadiwardoyo, Warisan Paulus Bagi Umat ..., hlm. 93-94.

${ }^{44}$ I. Suharyo, Menjadi Manusia Dewasa: Belajar dari Pengalaman Hidup St. Paulus (Yogyakarta: Kanisius, 2003), hlm.74-76. 
proses penciptaan baru yang tiada pernah henti. Dengan merenungkannya, Paulus merasakan sebagai ciptaan baru yang terusmenerus dibaharui tiada henti. ${ }^{45}$

\section{Refleksi atas Pertobatan Paulus}

Pertobatan adalah suatu peristiwa atau pengalaman pribadi seorang beriman yang telah menemukan dan mengalami Allah sebagai penyelamat. Peranan pribadi dalam tindakan pertobatan sangat besar karena akan menjalani dan mengalami sebuah proses yaitu: penyesalan, pengakuan, dan perbaikan. Dalam proses pertobatan itu, seorang pendosa akan sampai pada keharusan mengakui keberdosaannya, memohon ampun dan hukuman atas dosa dan kesalahannya, serta berjanji utuk tidak melakukan dosa dan kesalahan lagi. Tindakan pertobatan itu harus dilakukan dengan sikap kerendahan hati, kejernihan hati dan pikiran, serta bebas dan bertanggungjawab. ${ }^{46}$

Dalam proses pertobatan Paulus ada spiritualitas pertobatan yang mendalam dan nyata. Dalam proses pertobatan Paulus, disana ada gerakan atau dorongan yang kuat dari Yesus dan tanggapan Paulus, disana ada relasi yang semakin intim antara Yesus dan Paulus. Dari pihak Yesus, Yesus menjumpai dan menegur Paulus atas tindakannya yang salah. Dari pihak Paulus, Paulus tersentuh oleh teguran dan sapaan Allah. Berkat teguran Yesus itu Paulus tersadar atas kejahatan dan kesalahannya. Mata hati Paulus terbuka dan bisa melihat kebenaran tentang Yesus. Kemudian Paulus tergerak untuk bertobat dan mau dibaptis. Berkat pertobatannya, Paulus memperoleh daya untuk menjadi manusia baru yang semakin serupa, sepikiran, dan seperasaan dengan Yesus Kristus (Flp 2:5-11). ${ }^{47}$ Paulus berkata, "Aku hidup, tetapi bukan lagi aku sendiri yang hidup, melainkan Kristus yang hidup di dalam aku" (Galatia 2:20). Setelah pertobatannya dan hidup baru dalam Kristus, Paulus menjadi orang yang merdeka dan sungguh mengalami sukacita, damai sejahtera sehingga ia berani menjadi saksi dan Rasul Yesus dalam mewartakan Injil.

\footnotetext{
${ }^{45}$ I. Suharyo, Menjadi Manusia Dewasa ..., hlm.71-72 dan 75.

46 Albertus Sujoko, Praktek Sakramen Pertobatan dalam Gereja Katolik (Yogyakarta: Kanisius, 2012), hlm. 146; bdk. Laurensius Dihe S, Sakramen Tobat di Tengah Globalisasi ..., hlm. 49.

${ }^{47}$ Laurensius Dihe S, Sakramen Tobat di Tengab Globalisasi ..., hlm. 51.
} 
Apa yang telah terjadi dan dialami oleh Paulus dalam proses pertobatan dan spiritualitas hidupnya harus menjadi teladan dan model spiritualitas hidup orang kristiani yang mau bertobat dan ingin memiliki hidup yang baru dalam Kristus. Untuk sampai pada pertobatan sejati, setiap orang kristiani bisa saja mengalami sentuhan, sapaan, dan teguran Yesus ketika ia berdoa, membaca atau mendengar Sabda Tuhan, atau ketika ia mengalami kesepian rohani, penderitaan dan bahkan keberdosaan. Setelah tersentuh oleh kasih Yesus itu orang kristiani menjadi sadar akan dosa dan kesalahannya. Kemudian hatinya tergerak untuk bertobat dan hidup seturut kehendak Tuhan. Dari pertobatannya, ia memperoleh pengampunan dosa dan damai, serta menjadi manusia baru yang dipenuhi kasih Yesus. Buah-buah pertobatannya harus ditampakkan dalam tindakan dan perbuatan yang baik. Setelah bertobat, orang kristiani harus semakin memiliki relasi yang intim dengan Yesus dan terus menghidupi spiritualitas hidupnya secara lebih mendalam.

\section{Penutup}

Pengalaman hidup Paulus menjadi contoh dan teladan bagi orang yang mau bertobat. Paulus yang semula memusuhi Kristus bertobat dan menjadi manusia baru. Setelah menjadi baru dan hidup baru dalam Kristus, Paulus semakin bergembira dan bersukacita dalam menjalankan perutusannya. Ia percaya dan yakin bahwa apa yang sedang dikerjakannya adalah kehendak Allah dan karya Allah. Paulus menyadari bahwa apa yang hidup di dalam dirinya adalah Kristus. Sampai akhir hidupnya, Paulus tetap menjalankan panggilan dan perutusannya yaitu menjadi pewarta Injil dengan penuh semangat meskipun ia harus menderita seperti Yesus. Paulus memang mati, tetapi karyanya tetap hidup di dalam Gereja. Karyanya adalah sebuah warisan iman yang harus dibaca dan dihidupi oleh semua orang terutama para pengikut Yesus.

Pengalaman pertobatan Paulus memiliki spiritualitas yang mendalam. Orang-orang kristiani perlu belajar dari pengalaman pertobatan Paulus. Sebagai manusia yang cenderung jatuh ke dalam dosa dan bahkan mempunyai dosa dan kesalahan, orang-orang kristiani harus melakukan pertobatan terus-menerus dan memohon pengampunan dosa dan pendamaian dengan Allah. Pertobatan itu harus tumbuh dari dorongan hati, diakukan dan disesali dengan kerendahan hati untuk 
mengakui dosa dan kesalahan. Setelah manusia bertobat dan mendapat pengampunan dari Allah serta berdamai dengan Allah, buah-buah pertobatan harus tampak dalam sikap dan perbuatan yang baik dan nyata. Pertobatan sebagai sarana menjadi manusia baru dalam Kristus.

$===0000===$ 
Lagos. Durnal Filsafat-7ealogi. Vol. 15. No. 2. Yuni 2018

\section{DAFTAR PUSTAKA}

\section{Sumber Utama}

Dihe, Laurensius. Sakramen Tobat di Tengah Globalisasi. Yogyakarta: Kanisius, 2015.

Martini, C.M. Kesaksian Santo Paulus. Yogyakarta: Kanisius, 2001.

\section{Sumber Dokumen Gereja}

Katekismus Gereja Katolik. Diterjemahkan oleh Embuiru. Ende: Arnoldus, 1995.

Kitab Hukum Kanonik 1983 (Codex Iuris Canonici 1983). Edisi Resmi Bahasa Indonesia. Diterjemahkan oleh Sekretariat KWI. Jakarta: KWI, 2016.

Konsili Vatikan II. Diterjemahkan oleh R. Hardawiryana. Jakarta: Dokumentasi dan Penerangan KWI-Obor, 1993.

\section{Sumber Pendukung}

Aman, Peter C. Moral Dasar: Prinsip-prinsip Hidup Kristiani. Jakarta: Obor, 2016.

Barclay, William. Duta Bagi Kristus. (Judul asli: Ambrassador for Christ: The Life and Teaching of Paul, The Saint Andrew Press, 1980), diterjemahkan oleh D. Susilaradeya dan A. Susilaradeya. Jakarta: Gunung Mulia, 2009.

Barney, D. Kenneth. Surat Efesus. Malang. Gandum Emas, 1981.

Brunot, A. Paulus dan Pesannya. Yogyakarta: Kanisius 1992.

Darmawijaya, St. Sekilas Bersama Paulus. Yogyakarta: Kanisius, 1992. 
Yahanes Anjar Danabakti \& Stanislaus Skotska. Pertabatan Menjadi Sarana Menjadi Manusia Baru

Durken, Daniel (ed), The New Collegeville Bible Commentary: New Testament (Minnesota: Liturgical Press, 2008) diterjemahkan oleh Indra Sanjaya, Tafsir Perjanjian Baru. Yogyakarta: Kanisius, 2018.

George, V Shillington. Jesus And Paul Before Christianity. EugeneOregon: Cascade Books, 2011.

Groenen, C. Pengantar Ke Dalam Perjanjian Baru. Yogyakarta: Kanisius, 2006.

Hadiwardoyo, Purwa Al. Warisan Paulus Bagi Umat: Ajaran Iman, Pastoral, dan Moral. Yogyakarta: Kanisius, 2012.

Pertobatan Dalam Tradisi Katolik. Yogyakarta: Kanisius, 2011.

Jacobs, Tom. Paulus Rasul. Ende: Nusa Indah, 1985.

Paulus: Hidup, Karya dan Teologinya. Yogyakarta: Kanisius, 1983.

Rahmat Bagi Manusia Lemah. Yogyakarta: Kanisius, 2004.

Kustono, Ant. Hari. Paulus Dari Tarsus. Yogyakarta: Kanisius, 2012.

Leteng, Hubertus. Spiritualitas Pertobatan: Pintu Masuk Kerajaan Allah. Jakarta: Obor, 2010.

Mahulae, Kristinus. C. Paulus Rasul Kristus Yesus. Pematangsiantar: Fakultas Filsafat Unika St. Thomas, 2010. (Diktat Kuliah).

Manurung, Markus. Sudahkah Aku Mengaku Dosa. Medan: Bina Media Perintis, 2014.

Marsunu, YM Seto. Pengantar Surat-surat Paulus.Yogyakarta: Kanisius, 2020. 
Nadeak, Largus. Topik-topik Teologi Moral Fundamental. Medan: Bina Media Perintis, 2015.

Riyadi, St. Eko. Hidup dalam Kristus: Pengalaman Rohani St. Paulus dalam Peristiwa Damsyik. Yogyakarta: Kanisius, 2012.

Sanjaya, V Indra. Membaca Lima Kitab Pertama Alkitab I. Yogyakarta: Kanisius, 2007.

Seminari Tinggi Santo Paulus Kentungan. Bermenung Bersama Santo Paulus: Guru Bangsa-Bangsa. Yogyakarta: Kanisius, 2017.

Suharyo, I. Menjadi Manusia Dewasa: Belajar dari Pengalaman Hidup St. Paulus. Yogyakarta: Kanisius, 2003.

-----------. Paulus Rasul Bangsa-bangsa. Jakarta: Lembaga Biblika Indonesia, 2008.

Sujoko, Albertus. Praktek Sakramen Pertobatan dalam Gereja Katolik.Yogyakarta: Kanisius, 2012.

Swindoll, Charles. R. Paulus: Seorang Yang Penuh Kasih Karunia dan Tegar. Jakarta: Nafiri Gabriel, 2004.

Tandiassa, S. Teologia Paulus. Yogyakarta: Moriel Publishing House, 2008.

Tobin, Thomas. H. Warta Rohani Rasul Paulus. Ende: Nusa Indah, 2009.

Walker, Peter. In The Steps Of Saint Paul (Oxford: Lion Publishing, 2008), diterjemahkan oleh V. Indra Sanjaya. Yogyakarya: Kanisius, 2013.

Wright, N.T. What Saint Paul Really Said Was Paul Of Tarsus The Real Founder Of Christianity. England: Lion Publishing PK, 2002. 